\title{
Change in students' perception of profession during nursing education in Turkey: A longitudinal study
}

\author{
Yildiz Denat ${ }^{1}$ \\ Gülşah Gürol Arslan ${ }^{2}$ \\ Muazzez Şahbaz ${ }^{3}$
}

\begin{abstract}
Background: Progress in the nursing is only possible with nursing students who graduate with sufficient information and comprehension about their professions.

Objectives: This study aimed to investigate nursing students' professional perceptions during 4year undergraduate nursing program and to determine whether changes occur in this time frame

Desing and Methods: This study was designed as a longitudinal cohort survey research. Data were collected over a four -year period. The study sample was constituted of 137 undergraduate nursing students attending two Schools of Health located in the western Turkey. In this study, data were collected using the Information Form which was prepared by the investigators and the Perception of Nursing Profession Scale (PNPS).

Results: Students' PNPS mean scores were identified as $85.24 \pm 11.66$ for 'Time 1, 86.86 \pm 12.37 for

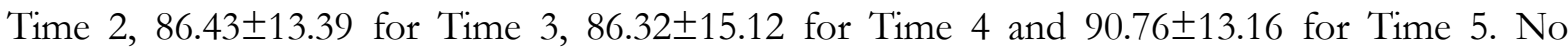
statistically significant differences were found in perception of nursing profession mean scores during nursing education ( $p>0.05$ ). Statistically meaningful differences were detected among students' "Professional Qualities" sub scale mean scores $(\mathrm{p}<0.05)$. Bonferroni test shows that the difference resulted from the fact that mean scores obtained at the end of Year 2 (Time 3) and Year 4 (Time 5) were higher than those obtained when students started nursing education (Time 1). No statistically significant differences were detected between "Professional Status" sub scale mean scores $(\mathrm{p}>0.05)$.

Conclusion: The results of this study indicated that freshmen students perceived the nursing profession rather positively and that influence continued throughout their education. It was identified that initial positive perceptions of students progressively increased at the end of $2^{\text {nd }}$ and 4th years. It was determined that students positively perceived the professional status of nursing and that the significant perceptions continued throughout their education.
\end{abstract}

Keywords: Education; Nursing Education; Nursing Students; Perception; Profession.

\footnotetext{
${ }^{1}$ Assistant Professor, Adnan Menderes University, Aydın Health High School·Fundamentals of Nursing, Aydın, Turkey, denat09@gmail.com

2 Assistant Professor, Dokuz Eylül University, Nursing Faculty, Fundamentals of Nursing, İzmir, Turkey, ggrolarslan@gmail.com

${ }^{3}$ Lecturer, Adnan Menderes University, Aydın Health High School, Fundamentals of Nursing, Aydın, Turkey, muazzez sahbaz@hotmail.com
} 
Denat, Y., Gürol Arslan, G., \& Șahbaz, M. (2016). Change in students' perception of profession during nursing education in Turkey: A longitudinal study. International Journal of Human Sciences, 13(1), 900-908. doi:10.14687/ijhs.v13i1.3462

\section{Introduction}

The most frequently asked questions during recruitment processes, career planning and entrance into post graduate programs are "Why do you want to be a nurse" (Cowin \& Johnson 2011:413) and "What kind of a nurse would you like to be". Professional perception has an important influence on the development of nursing students and the future quality of the nursing profession (Zhang \& Petrini 2008:274). The development of nursing is only possible with nursing students who graduate with sufficient information and comprehension regarding their profession (Karaöz 2004:129).

It is important for a professional in any career to acquire a professional identity and professional awareness (Dimitriadou et al., 2015:239). The foundations of professional awareness are laid during education, continue throughout professional life and facilitate the formation of a professional philosophy (Tunç et al., 2010 ; Cockrell 2002). It has been previously reported that the learning environment plays a critical role in determining the professional perceptions of students (Dimitriadou et al., 2015; Happell 2000).

The purpose of nursing school is to develop the nursing profession in line with societal realities (Tüfekçi \& Yıldız 2009:32). Nursing schools must recruit and retain qualified applicants to be able to solve current challenges in the profession. Perceptions of nursing have been linked to students' decisions to enter the nursing profession and to continue in, or withdraw from, nursing programs (Grainger \& Bolan 2006:38). The views of students who enroll in nursing education with social prejudices and a lack of information about the profession change positively or negatively as a result of the theoretical or practical training that they receive (Grainger \&Bolan 2006; Chen et al ., 2005).

Studies that investigated the influence of nursing education on professional perceptions have reported that the curriculum plays a crucial role in shaping student attitudes towards nursing profession (Zhang \& Petrini 2008 ; Nilsson \& Silén 2010 ; Tang et al., 2001). Manninen (1998) found that the curriculum affects students' nursing perceptions and professional development as they progress through the program (Manninen 1998). Dinç et al. (2007) reported that $42.7 \%$ of students had initial positive views when they first began their nursing education and that this percentage significantly increased to $70.7 \%$ as the number of applied lessons and the amount of their knowledge increased (Dinç et al., 2007). Bolan and Grainger (2009) pointed that students had relatively more positive attitudes towards nursing during the 4-year training period (Bolan \& Grainger 2009). In another study, it was identified that Canadian nursing students displayed differences in nursing perceptions between their first and fourth years of school (Grainger \&Bolan 2006).

Studies that investigated the influence of nursing education on professional perceptions have reported that curriculum, education process, number of applied lessons and the mounth of their knowledge increased, clinical learning environment, clinical learning experience and exposure to clinical experiences at early stages of curriculum plays a significant role in shaping students' perceptions towards nursing profession (Bolan \& Grainger 2009; Tang et al., 2001; Papastavrou et al., 2010; Wang et al., 2005). Most of these studies were designed as a comparison between first and fourth year training period or all training period.

During their education, the perception of nursing students towards nursing at the beginning is replaced by a more realistic comprehension of the nursing career. For this reason, it is necessary to observe professional comprehension of students over a long period. Longitudinal study of changes in students' perception of nursing will provide better results regarding revision of the curriculum. Additionally, studying the professional perception of students and factors causing this interaction will help to understand them in regard to their cultural backgrounds, which will provide knowledge to the candidates who enter the profession in the future. For this reason, in Turkey, it is necessary to obtain results from studies that observe the change in the professional perception of nursing students during their education period. Throughout the undergraduate program, students 
Denat, Y., Gürol Arslan, G., \& Șahbaz, M. (2016). Change in students' perception of profession during nursing education in Turkey: A longitudinal study. International Journal of Human Sciences, 13(1), 900-908. doi:10.14687/ijhs.v13i1.3462

will acquire different perspectives in theoretical and clinical training settings. As nursing education would take on a different approach, it is assumed that the approach to learning would also different which would also lead to an improvement of the utilization of clinical settings.

The present study aimed to achieve a better understanding of student perception and its evolution during the course of the 4 years of the undergraduate program. Our results can help nurse educators in evaluating the strengths and weaknesses of the educational program. This understanding could enhance curriculum development towards a caring and holistic paradigm of nursing.

\section{Purpose}

This study aimed to investigate nursing students' professional perceptions during 4-year undergraduate nursing program and to determine whether changes occur in this time frame.

\section{Method and Material}

\subsection{Population and sample selection}

The sample size was determined by using power calculation with the Gpower program. When the effect size is 0.03 and the error level is $(\alpha) 0.05$, a power of $(1-\beta) 0.85$ is achieved with a sample size of 75 . Taking into consideration of 1.8 study's design effect, this study 137 people were reached. A sample of nursing students attending two Schools of Health located in the western part of Turkey was used for this study. These schools have followed the same curriculum and educational process. The number of participants for each timepoint was determined by the number of students attending lectures on the day of the study (see Table 1).

Table 1: Sample size

\begin{tabular}{lr}
\hline Year & $\mathbf{n}$ \\
\hline Time 1 & 137 \\
Time 2 & 131 \\
Time 3 & 99 \\
Time 4 & 94 \\
Time 5 & 76 \\
\hline
\end{tabular}

During the 4 year period of the study, the sample size gradually decreased to 76 students in the final year. The main reasons for the decrease could be explained as the repeat students, absence on the specific day of data collection, health problems as well as transfer to another nursing school.

\subsection{Type of study}

This study was designed as a longitudinal cohort survey research.

\subsection{Data collection}

Data collection method; The data were collected over a four year period by research assistant. Data were collected at the beginning of the nursing education and at the end of each educational period.

Questionnaires were administered at the following timepoints:

Time 1: Entry into nursing education

Time 2: At the end of the first year

Time 3: At the end of the 2nd year

Time 4: At the end of the 3rd year

Time 5: At the end of the 4th year

Participants' demographic data regarding age, gender and school of last graduation were recorded at Time 1, and participants completed PNPS at Time 1, Time 2, Time 3, Time 4 and Time 5. 
Denat, Y., Gürol Arslan, G., \& Șahbaz, M. (2016). Change in students' perception of profession during nursing education in Turkey: A longitudinal study. International Journal of Human Sciences, 13(1), 900-908. doi:10.14687/ijhs.v13i1.3462

Students were required to write their ID numbers instead of names in the data collection form. Student ID numbers were used to keep track of each student' four year data. Data were kept by the principal investigator (RS) in a locked cabinet and on a password-protected computer for the electronic version. Data were analyzed by a statistical expert after the collection process was completed.

Data collection tools; Data were collected using the information form and Perception of Nursing Profession Scale (PNPS) developed in Turkey.

Information Form; This form was used to describe the sample feature. The form, which was prepared by the investigators, included demographic variables, such as age, gender, and most recent school graduated from.

Perception of Nursing Profession Scale (PNPS); The perceptions of students were measured using the PNPS. This scale was developed by Eşer et al. (Eşer et al., 2004). It contains 22 items and two sub-scales ('Professional Qualities' and 'Professional Status'). The items were measured on a five point Likert-type scale, ranging from one (strongly disagree) to five (strongly agree). 'Professional Qualities' sub-scale includes the following statements that explain various aspects of the profession: "nursing is a profession that requires intense communication and selfsacrifice; nursing is a profession based on knowledge and skill; nursing is a profession based on science; nursing is a profession that involves independent practices and requires teamwork; nursing is a profession that is satisfactory; nursing is a profession with hard working conditions; nursing is a profession that is exhausting; nursing is a profession that is stressful; nursing is a profession that requires the use of technology, problem-solving skills and higher education. The 'Professional Status' sub-scale consists of statements that include the position of nursing among other health professions, its prestige and status in society (Eşer et al., 2004).

The Cronbach's alpha coefficient for the scale was found to be 0.83 while the Cronbach's alpha coefficients for the sub-scales were found to be 0.85 and 0.79 for "Professional Qualities" and "Professional Status", respectively (Eşer et al., 2004). There is no cut off point on the PNPS. The highest score of the scale is 110 and the lowest score is 22; the highest score of the "Professional Qualities" sub-scale (17 items) is 85 while the lowest is 17 . As for the "Professional Status" sub-scale, the highest and lowest scores are 25 and 5, respectively. An increase in the total score obtained from the scale indicates positive professional perceptions (Eşer et al., 2004). In our study the Cronbach's alpha values are at each time point collected were: Time 1: 0.74, Time 2: 0.90, Time 3: 0.91, Time 4: 0.95, and Time 5: 0.91.

\subsection{Limitations of the study}

Limitations of the study includes the inability to continue the study with the initial number of students in subsequent years and the inclusion of students from only two nursing schools.

Due to the cross-sectional study design, students who have dropped out of the program are not represented in the sample and may, thus, represent a selection bias.

The researchers of this study were also instructors of the students taking part in this study. However, the data were collected by research assistant. This study reflects the findings of a Turkish sample and cannot be generalized to other contexts.

\subsection{Research ethics}

Written consent from both schools was obtained. Students were informed of the purpose of the study and were told that they had the right to withdraw at any time without adverse impact on their studies. After verbal agreement, the students were administered the questionnaire and were asked to return it in a sealed envelope to the research assistants during the class period.

\subsection{Evaluation of data}

Data were analyzed using the Statistical Package for Social Science 15.0 for windows (SPSS Inc, Chicago, IL, USA). Data were evaluated for mean, percentage, and variance for repeated measures and Bonferroni analysis. 
Denat, Y., Gürol Arslan, G., \& Șahbaz, M. (2016). Change in students' perception of profession during nursing education in Turkey: A longitudinal study. International Journal of Human Sciences, 13(1), 900-908. doi:10.14687/ijhs.v13i1.3462

\section{Results}

The mean age of the students was $18.89 \pm 1.35$, and $75.9 \%$ were female. Fifty-four percent of the participants last graduated from high school. Of the students who participated in the study, it was determined that $72.3 \%$ chose the profession willingly and $54 \%$ held a positive image of the profession before attending school.

Students' PNPS mean scores were identified as $85.24 \pm 11.66$ for Time $1,86.86 \pm 12.37$ for Time 2, 86.43 \pm 13.39 for Time 3, $86.32 \pm 15.12$ for Time 4 and $90.76 \pm 13.16$ for Time 5 . No statistically significant differences were found in the perception of nursing profession mean scores during nursing education ( $\mathrm{p}>0.05)$. "Professional Qualities" sub-scale mean scores of PNPS were found to be $68.96 \pm 9.52$ for Time 1, $70.82 \pm 10.16$ for Time 2, $70.83 \pm 11.15$ for Time 3, $70.90 \pm$ 12.89 for Time 4 and $73.94 \pm 9.98$ for Time 5. Statistically meaningful differences were detected among the "Professional Qualities" sub-scale mean scores $(\mathrm{p}<0.05)$. The Bonferroni test indicated that the differences resulted from the fact that mean scores obtained at the end of Year 2 (Time 3) and Year 4 (Time 5) were higher than those obtained at the beginning of nursing education (Time 1). PNPS "Professional Status" sub-scale mean scores were 16.28 \pm 4.14 for Time 1, 16.03 \pm 4.07 for Time 2, $15.48 \pm 4.37$ for Time 3, $15.35 \pm 4.57$ for Time 4 and $16.89 \pm 4.90$ for Time 5. No statistically significant differences were detected between "Professional Status" sub-scale mean scores $(\mathrm{p}>0.05)$ (Table 2).

Table 2: Distribution of PNPS and sub scale mean scores based on years

\begin{tabular}{|c|c|c|c|c|c|c|}
\hline PNPS and & $\begin{array}{l}\text { Time } 1 \\
(\mathrm{n}=137)\end{array}$ & $\begin{array}{l}\text { Time } 2 \\
(n=131)\end{array}$ & $\begin{array}{l}\text { Time } 3 \\
(n=99)\end{array}$ & $\begin{array}{l}\text { Time } 4 \\
(n=94)\end{array}$ & $\begin{array}{l}\text { Time } 5 \\
(n=76)\end{array}$ & \\
\hline Sub scores & Mean \pm SD & Mean士SD & Mean士SD & Mean $\pm S D$ & Mean士SD & $\mathrm{F} / \mathrm{p} *$ \\
\hline PNPS & $85.24 \pm 11.66$ & $86.86 \pm 12.37$ & $86.43 \pm 13.39$ & $86.32 \pm 15.12$ & $90.76 \pm 13.16$ & $\begin{array}{l}F=1.92, \\
p=0.11\end{array}$ \\
\hline $\begin{array}{l}\text { Professional } \\
\text { Qualities }\end{array}$ & $68.96 \pm 9.52$ & $70.82 \pm 10.16$ & $70.83 \pm 11.15$ & $70.90 \pm 12.89$ & $73.94 \pm 9.98$ & $\begin{array}{l}F=2.85 \\
p=0.03\end{array}$ \\
\hline $\begin{array}{l}\text { Professional } \\
\text { Status }\end{array}$ & $16.28 \pm 4.14$ & $16.03 \pm 4.07$ & $15.48 \pm 4.37$ & $15.35 \pm 4.57$ & $16.89 \pm 4.90$ & $\begin{array}{l}\mathrm{F}=1.23, \\
\mathrm{p}=0.30\end{array}$ \\
\hline
\end{tabular}

${ }^{*} \mathrm{p}<0.05$ is significant

\section{Discussion}

This study aimed to investigate nursing students' professional perceptions during 4-year undergraduate nursing programs in Turkey and to determine whether changes occur during that time frame. We found that first year students' perceptions regarding the nursing profession was relatively positive.

Studies undertaken in Turkey during the 1990s stated that nursing students did not possess sufficient desire or knowledge regarding nursing (Bayık et al., 1999; Kömürcü et al., 1998), and studies conducted in the 2000s reported that students' professional perceptions were relatively more positive (Tüfekçi \& Yildiz 2009; Dinç et al., 2007).

Transformations resulting from the dynamics of nursing, in addition to recent changes observed in every field, have led the field of nursing to undertake radical changes with the help of modern approaches and taking the unique conditions of our country into consideration (Kocaman 2004). Also, Turkey is currently in accession talks to join the European Union. The European reform movement has had an impact on nursing education. With the onset of the Bologna Process, harmonization was achieved in many countries in terms of embarking on the profession as well as the standards of academic degrees offered in undergraduate, master's and doctoral programs (Zgaga 2011). Several studies are underway in the health sector, especially nursing education in Turkey as part of adaptation to the member states of the European Union. In this regard, core curriculum 
Denat, Y., Gürol Arslan, G., \& Şahbaz, M. (2016). Change in students' perception of profession during nursing education in Turkey: A longitudinal study. International Journal of Human Sciences, 13(1), 900-908. doi:10.14687/ijhs.v13i1.3462

programs were designed and studies were conducted within the scope of the Bologna Process. These transformations affect societal views of the nursing profession, as well as the perceptions of students who are influenced by social culture.

The results of studies regarding student attitudes towards the nursing profession indicate that the changes observed in our country are similar to those reported worldwide (Zhang \&Petrini 2008 ; Grainger \&Bolan 2006).

Studies that focus on the influence of nursing education on professional perceptions have demonstrated that the curriculum has a crucial role in shaping student attitudes towards the nursing profession (Zhang \& Petrini 2008 ; Nilsson \& Silén 2010; Tang et al., 2001). This study was conducted in two nursing schools in Turkey with similar curriculums.

The present study has shown that the positive professional perceptions of first-year nursing students progressively increase throughout their education. A study conducted by Andersson (1993) in Switzerland reported that freshmen nursing students perceive nursing in a relatively traditional manner and that their perceptions continue throughout their education (Andersson 1993). A study conducted by Dinç et al. (2007) showed that $42.7 \%$ of the students had positive initial thoughts of nursing when they start nursing education. This ratio significantly rises to $70.7 \%$ with the increase in the number of theoretical and practical classes (Dinç et al., 2007). Similarly, studies have shown that student views on nursing positively change as they progress in their training and their perceptions differentiate (Bezci \& Baylk 2005). Manninen (1998) found that curriculum has more influence on students' nursing perceptions and professional development as they progress in the program (Manninen 1998). Bolan and Grainger (2009) reported that student attitudes towards nursing are increasingly positive over time during the 4-year training period (Bolan \& Grainger 2009).

The present study identified that students perceive the professional qualities of the nursing profession positively and that this positive perception continues throughout their education. Analyses showed that student perceptions on professional qualities significantly increased at the end of Year 2 and Year 4, compared with their initial perceptions. Nursing perceptions were found to differ between $1^{\text {st }}$ and $4^{\text {th }}$ years in a study on Canadian nursing students (Grainger \& Bolan 2006). Although students in both years regarded nursing "realistically", $4^{\text {th }}$ year students emphasized nurses as resource individuals, important experts and advocates with the ability to question physicians' orders and with independent practices. A study by Grainger and Bolan (2006) on $1^{\text {st }}$ and $4^{\text {th }}$ year students reported that students had positive images on nursing in general and had realistic views of the roles of nurses in both groups but reported distinctively more positive views in $4^{\text {th }}$ year students. Their study found that $4^{\text {th }}$ year nursing students had more powerful views on nursing education (Grainger \& Bolan 2006). The perceptions of nursing students on the nursing profession are the result of a complex process that involves the reasons for selecting the profession (Chen et al., 2005). It is believed that views of students who experience this process positively are positively influenced and that it also affects the results of the current study.

It has been reported that exposure to the clinical field during early stages of the nursing program is critical to perception of the nursing profession (Zhang \&Petrini 2008 ; Nilsson \& Silén 2010). The clinical learning field is the starting point for professional practices for nurses and contributes to the development of student views (Papathanasiou et al., 2014). According to the curriculum of nursing schools in which our study was conducted, students start clinical training after the first semester of the $1^{\text {st }}$ year. They undergo intense clinical training starting in the $2^{\text {nd }}$ year and acquire educational experiences in the field of community health care and education and management, in addition to clinical education in the $4^{\text {th }}$ year. In the current study, the differences between the perceptions of first-year (Time 1) students on professional quality of nurses and their perceptions at the end of the $2^{\text {nd }}$ and $4^{\text {th }}$ years are believed to be the result of their educational experiences based on the nursing education curriculum. One study identified that nursing students come to like the profession one week after they begin clinical practices (Wang et al., 2005). A study 
Denat, Y., Gürol Arslan, G., \& Șahbaz, M. (2016). Change in students' perception of profession during nursing education in Turkey: A longitudinal study. International Journal of Human Sciences, 13(1), 900-908. doi:10.14687/ijhs.v13i1.3462

by Demirkıran et al. (2005), which focused on the influence of clinical practices on student views regarding their professions, identified that the majority of students $(80.9 \%)$ had positive changes in their views about the profession after the first clinical practice (Demirkiran et al., 2005). A study by Eşer et al. (2008) determined that students' first clinical experiences positively affected the students' perceptions, specifically "professional qualities" (Demirkıran et al., 2005). In clinical settings, feeling as part of a team and being treated with respect as an individual were also identified as part of the socialization process that diminished anxiety, increased confidence and promoted the learning process (Papastavrou et al., 2010).

Initial perceptions of students who are influenced by the views of society on nursing when they begin nursing education are replaced by a realistic outlook of nursing during the process of training. This process requires the internalization of information, skills, attitudes, values and ethical standards related to nursing and making these a part of student behaviors. Internalization and development of professional identity is known as professional socialization (Professional nursing: concepts \& challenges. 3 ed. Philadelphia: WB Saunders; 2001). The present study identified that students positively perceived the professional status of nursing and that this perception was constant in the upcoming years. This finding may be related to the positive social viewpoints towards the nursing profession.

The results indicated that first-year students perceived the nursing profession relatively positively, a perception that continued throughout their education. Especially, the perceptions of students related to professional qualifications improved significantly at the end of $2^{\text {nd }}$ and $4^{\text {th }}$ years. The dimensions of professional qualifications will also provide nursing students with the ability to recognize their own attitudes towards professionalism. It was determined that students positively perceived the professional status of nursing and that the positive perceptions continued throughout their education. Nursing instructors suggestion to plan courses and activities in ways that will help to support students' positive perceptions about the nursing profession. Additional future studies should analyze the change in students' professional perception among different curriculums and also compare the findings to those of nursing programs of different countries.

\section{Conclusion and recommendations}

This study aimed to investigate nursing students' perceptions during a 4-year undergraduate nursing program and to determine whether changes occur during the educational time frame. The results of this study indicated that freshmen students perceived the nursing profession rather positively and that influence continued throughout their education but education did not lead to changes in the perception of the profession. Initial positive perceptions related to professional qualifications of students progressively increased at the end of 2 nd and 4 th years. The dimensions of professional qualifications will also provide nursing students with the ability to recognize their own attitudes towards professionalism. It was determined that students positively perceived the professional status of nursing and that the positive perceptions continued throughout their education. Additionally, our results indicate that nursing schools should revise their curriculum and acceptance policies for the nursing profession. Nursing instructors need to plan courses and activities in ways that will help to support students' positive perceptions about the nursing profession. Additional future studies should analyze the change in students' professional perception among different curriculums and also compare the findings to those of nursing programs of different countries.

\section{Acknowledgements}

The authors thank the nursing students who participated in this study. The authors also thank HŞK and FA for statistical analysis. 
Denat, Y., Gürol Arslan, G., \& Șahbaz, M. (2016). Change in students' perception of profession during nursing education in Turkey: A longitudinal study. International Journal of Human Sciences, 13(1), 900-908. doi:10.14687/ijhs.v13i1.3462

\section{References}

Andersson, EP. (1993). The perspective of student nurses and their perceptions of professional nursing during the nurse training programme. J Adv Nurs, 18(5):808-15.

Bayık, A., Durmuş, H., Uysal, A. (1999). Investigation of senior high school female students' professional selections and their views on nursing. VII National Nursing Congress Book. Erzurum: Atatürk University School of Nursing. 390-4.

Bezci, G., Bay1k, A. (2005). Nursing perceptions of nursing students. IV National Nursing Students Congress Book. Ankara: Kök Publications, 51.

Bolan, C., Grainger, P. (2009). Students in the BN program-do their perceptions change? Nurse Educ Today. 29 (7): 775-9.

Chen, XL., Chen, H., Xiu, Y. (2005). A study on education of professional attitude for nursing students. Chinese Nurs. Research. 19(9):1704-5.

Cockrell, EDS. (2002). Prenursing students' perceptions of the nursing profession. Unpublished master's thesis, Graduate Faculty of the Louisiana State University and Agricultural and Mechanical College, Bachelor of Science in Nursing (BSN) Program, Northwestern State University, Louisiana.

Cowin, LS., Johnson, M. (2011). Many paths lead to nursing: factors influencing students' perceptions of nursing. Int Nurs. Rev, 58(4):413-9.

Demirkıran, F., Türk, G., Denat, Y. (2005). Does the first clinical practice effect opinions of students concerning their profession? Journal of Ege University School of Nursing, 22(Special Issue):569-79.

Dimitriadou, M., Papastavrou, E., Efstathiou, G., Theodorou, M. (2015). Baccalaureate nursing students' perceptions of learning and supervision in the clinical environment. Nurs. Health Sci, 17(2):236-42.

Dinç, S., Kaya, Ö., Şimşek, Z. (2007). Harran Üniversitesi Sağllk Yüksekokulu Öğrencilerinin hemşirelik mesleği hakkındaki bilgi, düşünce ve beklentileri. Atatürk Üniversitesi Hemșirelik Yükesekokulu Dergisi, 10 (1): 1-19.

Eşer, I., Khorshid, L., Denat, Y. (2004). "Perception on Nursing Professional” scale development study. Cinar Dergisi, 10:31-9.

Eşer I., Khorshid, L., Denat, Y. (2008). The effect of the first clinical practice to the perception of nursing. Journal of Ege University School of Nursing, 24(1):15-26.

Grainger, P., Bolan, C. (2006). Perceptions of nursing as a career choice of students in the Baccalaureate nursing program. Nurse Educ. Today, 26(1):38-44.

Happell, B. (2000). Student interest in perioperative nursing practice as a career. $A O R N J$., 71(3):600-5.

Karaoz, S. (2004). Change in nursing students' perceptions of nursing during their education: the role of the Introduction to Nursing course in this change. Nurse Educ. Today, 24(2):128-35.

Kocaman, G (2004). Turkish nursing education problems and search for solutions. Turkish Journal of Research and Development in Nursing, Special Edition, 119-50.

Kömürcü, N., Erdoğan, N., Eti, F., Yıldırım, Z., Günay, N., Yazıcı, S. (1988). Marmara Üniversitesi Meslek Yüksekokulu Hemşirelik Bölümü ilk öğrencilerinin mesleği isteyerek seçip seçmeme durumları İle mezun olabilmeleri arasındaki ilişki. II. Ulusal Hemşirelike Eğitimi Sempošyum Kitabı, 162-170.

Manninen, E. (1998). Changes in nursing students' perceptions of nursing as they progress through their education. J Adv Nurs., 27(2):390-8.

Nilsson, AF., Silén, C. (2010). "You have to know why": The influence of different curricula on nursing students' perceptions of nursing. Scandinavian Journal of Education Research, 54:631-42.

Papastavrou, E., Lambrinou, E., Tsangari, H., Saarikoski, M., Leino-Kilpi, H. (2010). Student nurses experience of learning in the clinical environment. Nurse Educ Pract.,10(3):176-82. 
Denat, Y., Gürol Arslan, G., \& Șahbaz, M. (2016). Change in students' perception of profession during nursing education in Turkey: A longitudinal study. International Journal of Human Sciences, 13(1), 900-908. doi:10.14687/ijhs.v13i1.3462

Papathanasiou, IV., Tsaras, K., Sarafis, P. (2014). Views and perceptions of nursing students on their clinical learning environment: teaching and learning. Nurse Educ. Today, 34(1):57-60.

Professional nursing: concepts \& challenges. 3 ed. Philadelphia: WB Saunders; 2001.

Tang, D., Zhao, Y., Chen, TY., Hu, Q., Zhang, YL., Yang, HY. (2001). Discussions on strengthening nursing undergraduate students' professional thoughts education and its countermeasures. Journal of Dali Medical College, 10:120-2.

Tüfekçi, FG., Yildiz, A.(2009). The students' reasons of nursing preference and ideas about their future. Journal of Anatolia Nursing and Health Science, 12(1):31-7.

Tunç, GÇ., Akanse, N., Özdemir, A. (2010). Factors affecting nursing and health officer students' selection of profession. Maltepe University Journal Nursing Science and Art., 3(1):24-31.

Wang, BQ., Shang, LP., Jin, RH. (2005). Fostering of professional sensibility of nursing probationers. Chinese Nursing Research, 19:80-1.

Zgaga, P. (2011).The "external dimension" of the Bologna Process, [cited 2011 October 7]. Availablefrom:http://ec.europa.eu/education/programmes/mundus/conference06/zgaga. pdf.

Zhang, MF., Petrini, MA. (2008).Factors influencing Chinese undergraduate nursing students' perceptions of the nursing profession. Int. Nurs.Rev., 55(3):274-80. 